\title{
Incidence of Brucella species in marine mammals of the German North Sea
}

\author{
E. Prenger-Berninghoff ${ }^{1, *}$, U. Siebert ${ }^{2}$, M. Stede $^{3}$, A. König ${ }^{1,4}$, R. Weiß ${ }^{1}$, G. Baljer ${ }^{1}$ \\ ${ }^{1}$ Institut für Hygiene und Infektionskrankheiten der Tiere der Justus-Liebig-Universität Gießen, Frankfurter Strasse 85-89, \\ 35392 Giessen, Germany \\ ${ }^{2}$ Forschungs- und Technologiezentrum Westküste der Christian-Albrecht-Universität Kiel, Hafentörn 1, 25761 Büsum, Germany \\ ${ }^{3}$ Staatliches Veterinäruntersuchungsamt für Fische und Fischwaren Cuxhaven, Lentzkai 1, 27472 Cuxhaven, Germany
}

${ }^{4}$ Present address: Landesuntersuchungsamt Rheinland-Pfalz, Blücherstr. 34, 56073 Koblenz, Germany

\begin{abstract}
In this study, organ samples from 426 common seals Phoca vitulina, 298 harbour porpoises Phocoena phocoena, 34 grey seals Halichoerus grypus and 10 other marine mammals were assessed for the presence of Brucella species. Forty-seven common seals, 2 harbour porpoises and 1 grey seal were found to be positive for these bacteria. A total of 91 Brucella strains were successfully isolated, due to the fact that Brucella spp. were found in more than one organ sample in 15 animals. The primary organ in which the bacteria were present was the lung. In addition, 2 strains were isolated from lungworms (Parafilaroides spp.). Forty-nine of the isolated strains were selected for further analysis using conventional phenotyping methods. Molecular characterisation was carried out by analysing the IS711 and omp2 loci. With respect to the distribution of the IS711 loci in the genome, the 49 field isolates differed strongly from the terrestrial Brucella species and marginally from the marine Brucella reference strain NCTC12890. Based on the results of the PCR restriction fragment length polymorphism (PCR-RFLP) investigation of the omp2 locus, the majority of the Brucella field isolates were classified as $B$. pinnipediae, recently proposed $B$. pinnipedialis, possessing 1 omp 2 a gene and 1 omp $2 b$ gene. Two field isolates revealed the presence of 2 omp $2 a$ genes, as has been described for Brucella ovis. To our knowledge, these results confirm for the first time the presence of Brucella species in the marine mammal population of the German North Sea. These findings highlight the need for additional research on the relevance of these Brucella species for marine hosts and their environment.
\end{abstract}

KEY WORDS: Brucella species - Marine mammals · Phenotypic and molecular investigation German North Sea

Resale or republication not permitted without written consent of the publisher

\section{INTRODUCTION}

Since 1994, Brucella species have been isolated from various marine mammal species inhabiting several geographic regions (Ewalt et al. 1994, Ross et al. 1994, 1996, Foster et al. 1996, 2002, Garner et al. 1997, Clavareau et al. 1998, Forbes et al. 2000). The marine Brucella isolates can be distinguished from the terrestrial Brucella species using conventional phenotypic investigation analyses of, for example, $\mathrm{CO}_{2}$ requirement, urease activity, $\mathrm{H}_{2} \mathrm{~S}$ production, agglutination with monospecific antisera, growth in the presence of different dyes and oxidative metabolism pattern (Alton et al. 1988, Foster et al. 1996, Garner et al. 1997, Jahans et al. 1997, Clavareau et al. 1998, Forbes et al. 2000, Jacques et al. 2007).

Studies which employed fingerprinting of the genusspecific mobile genetic element IS711 observed a difference in the number and distribution of IS711 copies between the genome of the marine Brucella isolates and that of the terrestrial Brucella species. The marine mammal isolates contained more IS711 copies and possessed at least one specific IS711 copy present in all 
marine Brucella isolates (Clavareau et al. 1998, Bricker et al. 2000, Cloeckaert et al. 2000).

A further distinction of the marine Brucella species is possible when analysing the genus-specific omp2locus. This locus consists of the 2 closely related genes omp2a and omp2b. Both share an approximated $85 \%$ DNA homology; they are separated by $900 \mathrm{bp}$ and oriented in opposite directions (Ficht et al. 1989). Current data suggest the gene arrangement is conserved in all Brucella species. Therefore, distinction between the Brucella species and some of their biovars can be performed by PCR-restiction fragment length polymorphism (PCR-RFLP) analysis (Cloeckaert et al. 1995). In a further study, Cloeckaert et al. (2001) obtained data which led to a subdivision of the marine Brucella isolates into 2 groups. The strains isolated from seals and 1 otter possessed 1 omp2a and 1 omp2b gene, representing the formerly proposed species $B$. pinnipediae. In contrast, Brucella isolates from dolphins and porpoises possessed no omp2a but 2 omp $2 b$ genes, thus identifying these isolates as $B$. cetaceae (Cloeckaert et al. 2001). Brucella isolates from Pacific common minke whales Balaenoptera acutorostrata revealed omp2a and omp $2 b$ genes with motifs very similar to Atlantic marine strains as well as to terrestrial strains thus showing them to be chimeric between marine and terrestrial strains (Ohishi et al. 2005).

Oxidative metabolic profiles as well as variable number of tandem repeats (VNTR) typing and multilocus sequence analysis (MLSA) of marine Brucella isolates revealed the existence of 3 different groups, one comprising mainly pinniped isolates and the other 2 consisting of either porpoise or dolphin isolates (Groussaud et al. 2007, Jacques et al. 2007). The recently proposed classification of Brucella isolated from marine mammals is based on phenotypic and molecular methods and comprises $B$. pinnipedialis which prefer seal hosts, and B. ceti which prefer cetacean hosts (Foster et al. 2007). The pathogenic potential of these 2 Brucella species for marine mammals remains unknown. Reproductive disorders such as placentitis or abortion in connection with the isolation of Brucella species were only present in a few cases (Ewalt et al. 1994, Miller et al. 1999). The transmission to terrestrial animals has been shown to be possible in experiments performed with sheep and cattle (Rhyan et al. 2001, Foster et al. 2002). Furthermore, human infections with marine Brucella isolates have also been reported. A research laboratory worker was proved to be infected with a cetacean Brucella isolate (Brew et al. 1999), and B. pinnipediae was isolated from 2 Peruvian patients with central nervous system disease (Sohn et al. 2003). Characterisation of a Brucella strain isolated from a patient with spinal osteomyelitis in New Zealand revealed a close relationship with Brucella sp. originat- ing from a United States bottlenose dolphin Tursiops truncatus and common seals Phoca vitulina (McDonald et al. 2006).

The aim of the present study was to determine whether Brucella species are present in marine mammals inhabiting the German part of the North Sea and to classify the obtained isolates via pheno- and genotyping.

\section{MATERIALS AND METHODS}

Sampling. The health status of marine mammals from the German North Sea was determined in the course of a national health monitoring program. The examined marine mammals were either stranded, accidentally caught in fishing nets or inhabitants of one of the 2 German seal rehabilitation centres. Tissue samples from 426 common seals Phoca vitulina, 298 harbour porpoises Phocoena phocoena, 34 grey seals Halichoerus grypus, 3 hooded seals Cystophora cristata, 3 common dolphins Delphinus delphis, 1 white beaked dolphin Lagenorhynchus albirostris, 1 ringed seal Phoca hispida, 1 pilot whale Globicephala melas and 1 minke whale Balaenoptera acutorostrata were evaluated for the presence of Brucella species. All animals originated from the German North Sea, except 1 common seal which was found in the port of Hamburg. Each individual underwent a full necropsy including further investigations (histopathological examinations, parasitological screening and morbillivirus immunohistochemistry) as described by Siebert et al. (2001). Organ samples and lungworms, if available, were stored at $-20^{\circ} \mathrm{C}$ until further processing.

Bacterial culturing and phenotype analysis. Prior to preparing bacterial cultures, the thawed samples were flame-decontaminated and incised with sterile scissors. The freshly incised area was placed on Brain Heart Infusion agar (Oxoid) supplemented with $5 \mathrm{~g}$ yeast (Oxoid), $50 \mathrm{ml}$ sheep blood and aqua destillata up to $1000 \mathrm{ml}$ and Brucella agar (Merck) supplemented with 2 ampoules of Brucella selective supplement (SR0083, Oxoid), $1.4 \mathrm{ml}$ crystal violet $0.1 \%$ (Merck) and aqua destillata up to $1000 \mathrm{ml}$. Lungworms were incised with a sterile scalpel and the freshly incised area was placed on the media described above. The cultures were incubated for at least $7 \mathrm{~d}$ at $37^{\circ} \mathrm{C}$ in an atmosphere of $10 \% \mathrm{CO}_{2}$.

The phenotype analysis (of carbon dioxide requirement, $\mathrm{H}_{2} \mathrm{~S}$ and urease production, dye sensitivity and agglutination with the 3 Brucella monospecific antisera $A, M$ and $R_{i}$ Federal Institute for Risk Assessment) was performed as described by Alton et al. (1988). Dye sensitivity was tested using basic fuchsin, thionin and safranin supplemented in a concentration of 10,20 and $40 \mu \mathrm{g}$ per ml of tryptose soy agar (Merck), respectively. 
Molecular analysis. DNA was isolated using the DNEasy Tissue Kit (Qiagen) and precipitated with ethanol according to the manufacturer's instructions. Fingerprinting of the IS711 locus was carried out with minor variations as described previously (Southern 1975, Chomczynski 1992, Bricker \& Halling 1994, Clavareau et al. 1998, Bricker et al. 2000). Briefly, 1 ug of genomic DNA was enzymatically digested overnight at $37^{\circ} \mathrm{C}$ with $40 \mathrm{U}$ ECoRI. The resulting fragments were separated by electrophoresis in a $0.8 \%$ agarose gel. After exposure to ultraviolet light (254-312 nm; $60 \mathrm{~mJ} \mathrm{~cm}^{-2}$ ), washing twice in $0.25 \mathrm{~N} \mathrm{HCl}$ and denaturing (1.5 M NaCl, 0.5 M NaOH), the DNA was then transferred to a nylon membrane (Roche). Following neutralisation (1.5 M NaCl, 0.5 M Tris pH 8, $1 \mathrm{mM}$ EDTA pH 8) the blot was dried and baked at $120^{\circ} \mathrm{C}$ for $30 \mathrm{~min}$. Prehybridisation was performed for $1 \mathrm{~h}$ in aqueous hybridisation buffer $(50 \%$ formamide, $5 \times$ saline sodium citrate (SSC), $2 \%$ blocking reagent, $0.1 \%$ N-lauroylsarkosin, $0.02 \%$ sodium dodecyl sulphate, SDS). The digoxigenin (DIG)-labelled IS711 probe was prepared by PCR amplification of the IS711 loci of the marine Brucella reference strain NCTC12890 according to the manufacturer's instructions (DIG DNA-Labelling Kit, Boehringer). The labelled probe was denatured (10 min boiling) and then added to the hybridisation buffer. Hybridisation was performed for $18 \mathrm{~h}$ at $42^{\circ} \mathrm{C}$. The membrane was then washed, blocked, incubated with anti-DIG alkaline phosphatase-conjugated Fab-antibody and washed according to the manufacturer's instructions for the DIG Luminescent Detection Kit (Boehringer). Luminescence was recorded on Cronex medical radiographic films 4 (Siemens) for 1 to $2 \mathrm{~h}$.

The omp2 PCR was performed with primer pairs $2 \mathrm{aA}, 2 \mathrm{aB}(o m p 2 a)$ and $2 \mathrm{bA}, 2 \mathrm{bB}(o m p 2 b)$ as well as the amplification protocol described by Cloeckaert et al. (1995) (for details see Table 1). Amplification reactions were performed in $50 \mu \mathrm{l}$ volumes containing 20× Tfl reaction buffer (Biozym), $25 \mathrm{mM} \mathrm{MgCl}_{2}, 16 \mathrm{mM}$ deoxyribonucleotide triphosphate (dNTP), $20 \mu \mathrm{M}$ primer,

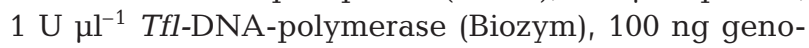
mic DNA and aqua destillata.

The restriction digestion was carried out according to Cloeckaert et al. (1995). The restriction enzymes AluI, ClaI, HaeIII, HinfI, KpnI and PvuII were purchased from Amersham; BanI, NcoI and StyI from New England Biolabs; BglII, EcoRI and PstI from MBI Fermentas; and TaqI from Sigma. Buffers and incubation temperatures were used as recommended by the manufacturers. Agarose gel electrophoresis was performed as described previously (Cloeckaert et al. 1995).

The amplicons were sequenced based on the dideoxy-chain-termination method (Sanger et al. 1977). In addition to the primers applied above $(2 \mathrm{aA}, 2 \mathrm{aB}$,
$2 \mathrm{bA}$ and 2bB), 2 further primers were established (2b470 and 2b609; Table 1) to verify sequence readout. The primers $2 \mathrm{~b} 470$ and $2 \mathrm{~b} 609$ were established with OLIGO ${ }^{\circledR}$ primer analysis software 4.0. Sequences were aligned using LASERGENE ${ }^{\circledR}$ Seqman II software. The statistical evaluation of the constructed phylogenetic tree was performed by bootstrap analysis (Felsenstein 1985) using the program 'Seqboot' (PHYLIP-package) with 100 replicates. All primers used in the present study were purchased from Roth.

\section{RESULTS}

Specimens from 426 common seals, 298 harbour porpoises, 34 grey seals and 10 other marine mammals were examined to detect Brucella species. Each of the 91 Brucella isolates was obtained from an organ sample taken from common seals $(\mathrm{n}=47)$, grey seal $(n=1)$ and harbour porpoises $(n=2)$. Most of these animals were suffering from verminous bronchopneumonia. From the common seals, 39 Brucella isolates were obtained from lung tissue or lung lymph nodes, 19 isolates from the digestive tract, 11 strains from the spleen, 7 strains from the kidneys and 7 strains from the liver. One isolate was found in tongue and skin samples. Two isolates were obtained from lungworms

Table 1. Primer sequences used for PCR and sequencing (targeting the omp2a and omp2b genes)

\begin{tabular}{|ll|}
\hline Primer & Sequence $\left(5^{\prime}-3^{\prime}\right)$ \\
\hline $2 \mathrm{aA}$ & GGCTATTCAAAATTCTGGCG \\
$2 \mathrm{aB}$ & ATCGATTCTCACGCTTTCGT \\
$2 \mathrm{bA}$ & CCTTCAGCCAAATCAGAATG \\
$2 \mathrm{bB}$ & GGTCAGCATAAAAAGCAAGC \\
$2 \mathrm{~b} 470$ & ATTCGGATTCGTCGATAC \\
$2 \mathrm{~b} 609$ & CGCTCTCGAACAGGGTGG \\
\hline
\end{tabular}

Table 2. Brucella spp. infecting Phoca vitulina. Number of strains isolated and analysed from common seals, and the locus of isolation

\begin{tabular}{|lcc|}
\hline $\begin{array}{l}\text { Locus of } \\
\text { isolation }\end{array}$ & $\begin{array}{c}\text { No. isolated } \\
\text { strains }\end{array}$ & $\begin{array}{c}\text { No. analysed } \\
\text { isolates }\end{array}$ \\
\hline Lung & 32 & 22 \\
Lung lymph nodes & 7 & 3 \\
Digestive tract & 10 & 4 \\
Digestive tract lymph nodes & 9 & 3 \\
Spleen & 11 & 5 \\
Kidney & 7 & 3 \\
Liver & 7 & 3 \\
Tongue and skin & 2 & 2 \\
Lungworm & 2 & 2 \\
Total & 87 & 47 \\
\hline
\end{tabular}


of Brucella-positive seals (Table 2). A single isolate from a grey seal was found in lung tissue and 3 isolates from harbour porpoises were obtained from lung, kidney and mesenteric lymph nodes. All isolates became apparent on BHI- and Brucella-agar after 3 to $5 \mathrm{~d}$ of incubation at $37^{\circ} \mathrm{C}$ in $10 \% \mathrm{CO}_{2}$-enriched atmosphere, the latter condition being essential for bacterial growth.

Forty-nine isolates from 2 lungworms and different organs of 28 common seals (Table 2), 1 grey seal and 1 harbour porpoise were selected as representative strains for further biotyping and molecular analysis. All tested isolates produced urease and grew in the presence of the dyes fuchsin, thionin and safranin (except strain no. 8: sensitive to $40 \mu \mathrm{g} / \mathrm{ml}$ thionin). None of the isolates showed $\mathrm{H}_{2} \mathrm{~S}$ production. All tested isolates agglutinated in the presence of monospecific antiserum A, whereas no agglutination was observed in the presence of monospecific antiserum M or R.

The number and distribution of IS711 copies in marine Brucella genomes determined by Southern blot of EcoRI-digested DNA probes with DIG-labelled IS711 are shown in Fig. 1. All investigated marine Brucella field isolates $(\mathrm{n}=49)$ contained at least 23 IS711 copies in their genome and showed identical hybridisation patterns. Furthermore, the marine-specific IS711 copy on the $1.7 \mathrm{~kb}$ EcoRI fragment was observed in the genome of the 49 field isolates. In contrast to the marine reference strain NCTC12890, all tested isolates lacked an IS711 fragment in the range of the $3 \mathrm{~kb}$ EcoRI fragment.

Previous studies observed different restriction amplification patterns for Brucella isolates of the omp2 locus determined by PCR-RFLP and used letters to classify these patterns (Cloeckaert et al. 1995, 2001). Following this classification, all tested marine field isolates displayed the restriction pattern I for their omp2a gene. For the omp $2 b$ gene, 43 isolates showed restriction pattern L (Fig. 2a), 1 grey seal isolate (no. 9) pattern $\mathrm{O}$ and 1 common seal isolate (no. 44) pattern M. The common seal isolate no. 22 could not be classified because of an ECoRI restriction pattern different from those described by Cloeckaert et al. (2001). Two common seal field isolates (nos. 8 and 10) represented an 'omp $2 b$ ' restriction pattern (quotation marks are used here to distinguish this apparent omp2a gene positioned at the locus of the omp2b gene

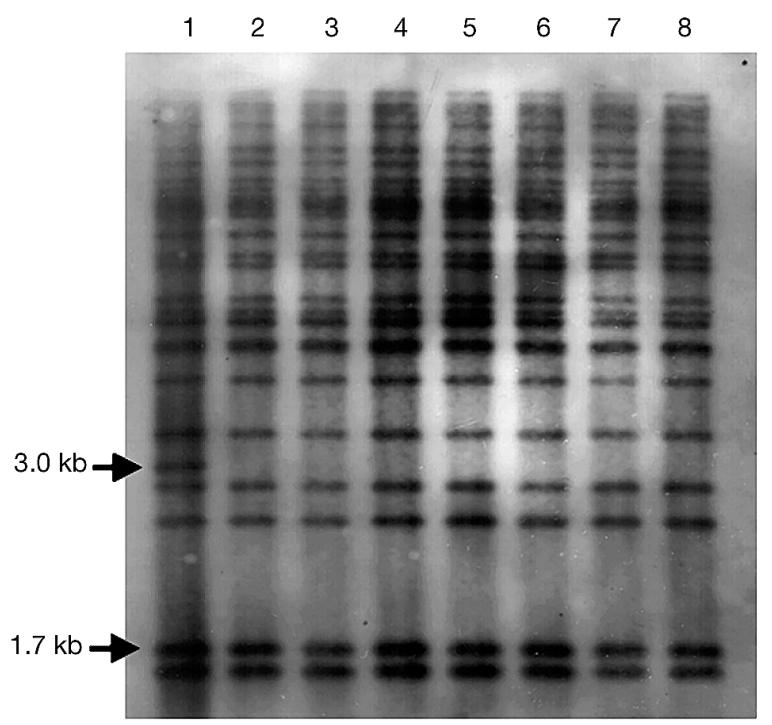

Fig. 1. Southern blot of EcoRI-digested DNA from Brucella reference strain NCTC12890 (Lane 1) and 7 Brucella field isolates (Lanes 2-8) probed with IS711-DNA including isolates no. 8 (Lane 3) and 17 (Lane 4). All field isolates demonstrated the same hybridisation pattern including the marine Brucella isolate-specific $1.7 \mathrm{~kb}$ band. The reference strain displayed 1 additional band in the range of $3 \mathrm{~kb}$
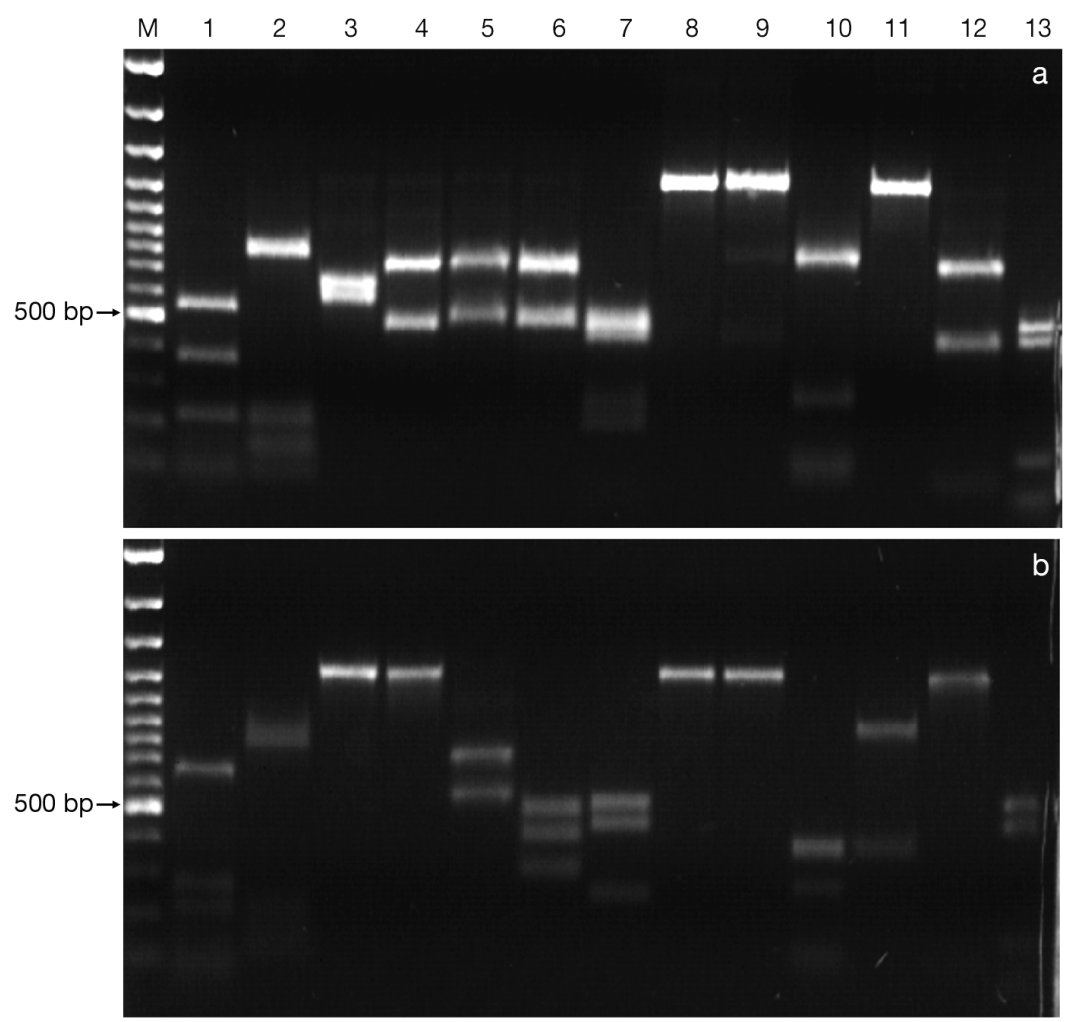

Fig. 2. Restriction patterns of PCR-amplified omp $2 b$ gene of the marine Brucella isolates no. 17 (a) and 8 (b) cut by AluI (Lane 1), BanI (Lane 2), BglII (Lane 3), ClaI (Lane 4), EcoRI (Lane 5), HaeIII (Lane 6), Hinf III (Lane 7), KpnI (Lane 8), NcoI (Lane 9), PstI (Lane 10), PvuI (Lane 11), StyI (Lane 12) and TaqI (Lane 13). Note the differences between the restriction patterns of the omp $2 b$ gene from isolate no. 17 and 'omp $2 b^{\prime}$ from isolate no. 8. Lane M: marker (100 bp ladder plus) 
from the usual omp $2 b$ gene) which was nearly identical with their omp2a restriction pattern (Fig. 2b).

Nucleotid sequencing of the omp2a and 'omp $2 b$ ' genes of the Brucella field isolate no. 8 (GenBank accession numbers DQ059380 and DQ0593801) demonstrated a homology of $95.2 \%$. Construction of the phylogenetic tree demonstrated the highest degree of relationship of the isolate no. 8 ' $\mathrm{mp} 2 b^{\prime}$ ' gene to the marine Brucella omp2a gene of a harbour seal (Fig. 3). Comparison of the omp2a gene of isolate no. 8 with the omp2a sequence AF300819 from the common seal strain NCTC12890 resulted in 100\% similarity, whereas comparison of the 'omp $2 b$ ' gene with the omp $2 b$ sequence AF300818 showed a lower similarity of $91.3 \%$.

\section{DISCUSSION}

There have to date been a number of reports of Brucella infections in marine mammals living in different marine ecosystems of the southern and northern hemisphere (reviewed in Foster et al. 2002). The aim of the present study was to identify and characterise Brucella

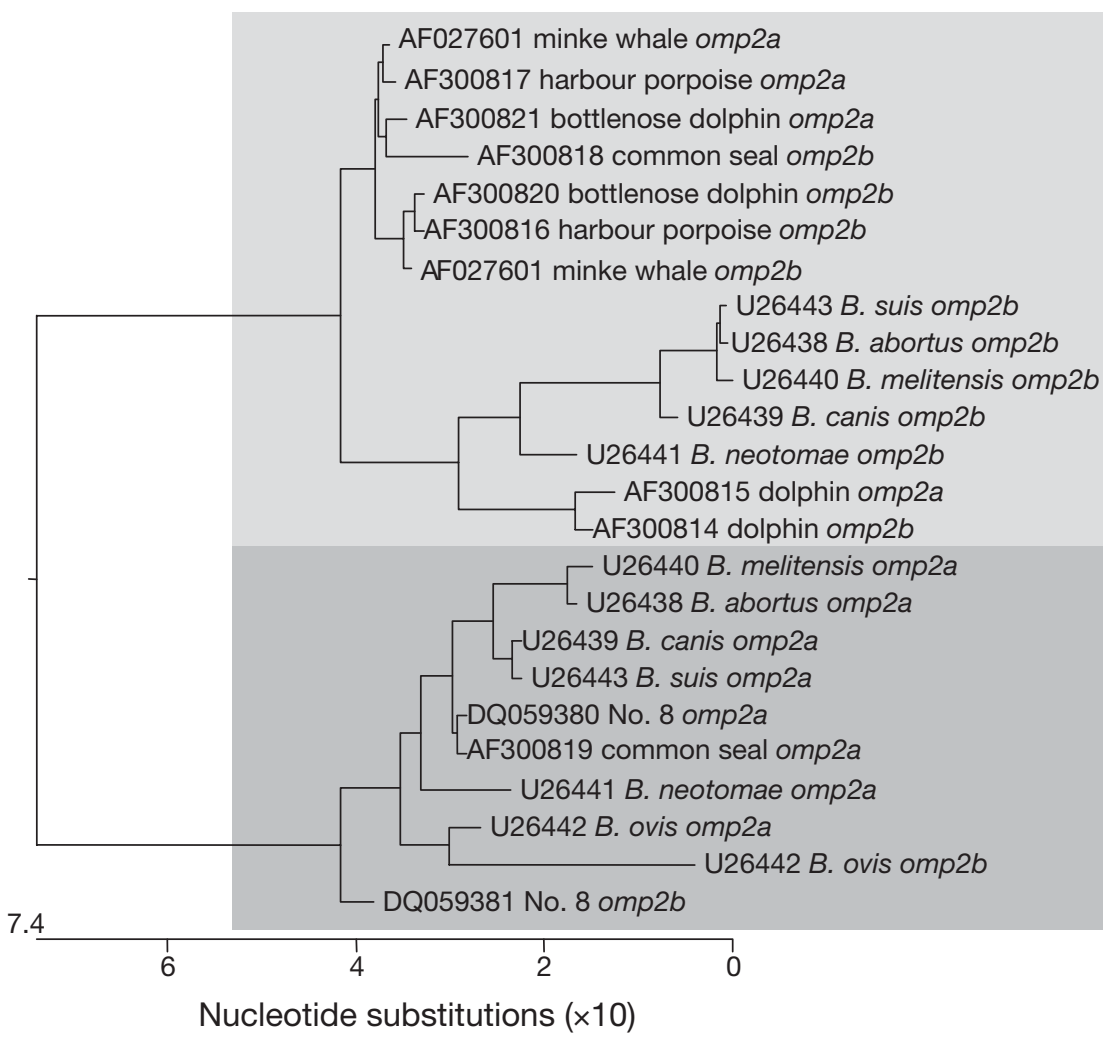

Fig. 3. Phylogenetic tree of different Brucella isolates after alignment of omp2a and omp $2 b$ gene sequences (sequence alignment with ClustalW [Slow/Accurate, International Union of Biochemistry standard genetic codes], construction of the phylogenetic tree with the neighbor-joining-method. Light grey shading comprises omp $2 b$ and dark grey shading omp $2 a$ gene sequences strains isolated from marine mammals of the German North Sea and clarify how they correspond to marine Brucella isolates from other geographical regions. Brucella species were detected in $11 \%$ of the investigated common seals, $0.7 \%$ of the harbour porpoises and $2.9 \%$ of the grey seals investigated. The greater number of Brucella isolates recovered from common seals may be related to their social behaviour. They gather in large numbers on sandbanks to rest and give birth to their offspring; this crowding might enhance the risk of an infection with Brucella species.

We obtained a significant number of strains from lung tissue which corresponded to data from previous studies (Garner et al. 1997, Foster et al. 2002). In most cases, pathological examinations diagnosed a suppurative, necrotising or granulomatous bronchopneumonia in association with lungworm infection and secondary bacterial infections by $\beta$-haemolytic streptococci (Swenshon et al. 1998, Siebert et al. 2001). Because of the occurrence of other bronchopneumoniacausing agents the significance of Brucella isolates remains unclear. The isolation of marine Brucella sp. from lungworms (Parafilaroides spp.) as well as from marine mammals with verminous bronchopneumonia suggests that transmission of marine Brucella strains by lungworms is possible. Garner et al. (1997) detected marine Brucella strains in uterine and gut lumen of lungworms. However, the possibility of Brucella infection prior to the entry of lungworms, which then ingest the bacteria, should be kept in mind.

For further characterisation, 49 of the isolated marine Brucella strains were investigated by conventional phenotypic methods. All strains demonstrated a $\mathrm{CO}_{2}$-dependent growth, a phenomenon previously described in Brucella isolates from seals (Foster et al. 1996, 2002, Jahans et al. 1997, Payeur et al. 1998, Forbes et al. 2000). Cetacean strains are usually able to grow without $\mathrm{CO}_{2}$ supplement; however, the only cetacean strain involved in the present study did not show this ability.

In terms of their positive urease activity, missing $\mathrm{H}_{2} \mathrm{~S}$ production, A-dominant LPS profile and low sensitivity to the dyes fuchsin, thionin and safranin (except strain no. 8), none of the tested isolates differed from earlier reports (Garner et al. 1997, Jahans et al. 1997, Clavareau et al. 1998, Payeur et al. 1998, Forbes et al. 2000). To further dif- 
ferentiate the marine Brucella strains, IS711 fingerprinting was carried out. Compared to classical Brucella strains (except B. ovis), all 49 marine isolates from the German North Sea possessed a higher number of IS711 copies in their genome. These findings correspond to the results of Bricker et al. (2000), as does the detection of the marine specific IS711 copy on the $1.7 \mathrm{~kb}$ EcoRI fragment. The hybridisation patterns indicate a close relationship between the investigated Brucella isolates and the reference strain NCTC12890 which originates from a common seal from the British coast.

To detect polymorphism between the German isolates, PCR-RFLP of the omp2 locus was performed based on the data from previous studies (Cloeckaert et al. 1995, 2001). All tested isolates revealed omp2a restriction pattern I, which has also been detected in the majority of omp2a genes from other North Sea seal isolates, including the reference strain NCTC12890 (Cloeckaert et al. 2001). Furthermore, the omp2a sequence from this reference strain has recently been proven to be identical to that of North Pacific minke whales (Ohishi et al. 2004). With regard to the omp2b gene, 5 isolates differed from the most frequently detected pattern $\mathrm{L}$, which has also been des-cribed for the seal reference strain (Cloeckaert et al. 2001). Interestingly, 2 isolates showed an 'omp $2 b$ ' gene pattern very similar to their omp2a pattern, suggesting the presence of 2 omp2a genes. The sequence alignment results support this hypothesis, as we were able to demonstrate a high similarity between both omp2 genes. Furthermore, the close relationship of both genes was confirmed by the phylogenetic tree. To date, only the omp2 locus of Brucella ovis has been described as consisting of 2 omp2a genes.

Phenotyping and genotyping methods revealed no differences between the German seal isolates and the cetacean strain investigated in this study. One potential reason might be the close vicinity of seals and cetaceans in the restricted area of the German North Sea. The results of this study might suggest that Brucella is endemic in this region. Infection of nonpreferred host species has been described for Brucella in endemic regions (Verger et al. 1989).

In summary, we were able to classify 47 of the 49 marine Brucella isolates as members of the formerly proposed species $B$. pinnipediae. The rarity of detecting differences between the reference strain NCTC12890 and the German Brucella isolates might result in their classification as B. pinnipedialis. This study confirms for the first time the presence of Brucella species in the marine mammal population of the German North Sea. These findings highlight the urgent need for additional research on the transmission, zoonotic potential and pathogenic relevance of these Brucella species for marine hosts and their environment.
Acknowledgements. The marine mammals in SchleswigHolstein were collected and investigated with funding from the Schleswig-Holstein Ministry of Agriculture, Environment and Rural Areas and the National Park Office of SchleswigHolstein.

\section{LITERATURE CITED}

Alton GG, Jones LM, Angus RD, Verger JM (1988) Techniques for the Brucellosis Laboratory. Institut National de la Recherche Agronomique, Paris

> Brew SD, Perrett LL, Stack JA, MacMillan AP, Staunton NJ (1999) Human exposure to Brucella recovered from a sea mammal. Vet Rec 144:483

> Bricker BJ, Halling SM (1994) Differentiation of Brucella abortus bv. 1, 2, and 4, Brucella melitensis, Brucella ovis, and Brucella suis bv. 1 by PCR. J Clin Microbiol 32: 2660-2666

> Bricker BJ, Ewalt DR, MacMillan AP, Foster G, Brew S (2000) Molecular characterization of Brucella strains isolated from marine mammals. J Clin Microbiol 38:1258-1262

> Chomczynski P (1992) One-hour downward alkaline capillary transfer for blotting of DNA and RNA. Anal Biochem 201:134-139

Clavareau C, Wellemans V, Walravens K, Tryland M and others (1998) Phenotypic and molecular characterization of a Brucella strain isolated from a minke whale (Balaenoptera acutorostrata). Microbiology 144:3267-3273

Cloeckaert A, Verger JM, Grayon M, Grepinet O (1995) Restriction site polymorphism of the genes encoding the major $25 \mathrm{kDa}$ and $36 \mathrm{kDa}$ outer-membrane proteins of Brucella. Microbiology 141:2111-2121

Cloeckaert A, Grayon M, Grepinet O (2000) An IS711 element downstream of the $b p 26$ gene is a specific marker of Brucella spp. isolated from marine mammals. Clin Diagn Lab Immunol 7:835-839

- Cloeckaert A, Verger JM, Grayon M, Paquet JY, GarinBastuji B, Foster G, Godfroid J (2001) Classification of Brucella spp. isolated from marine mammals by DNA polymorphism at the omp2 locus. Microbes Infect 3:729-738

Ewalt DR, Payeur JB, Martin BM, Cummins DR, Miller WG (1994) Characteristics of a Brucella species from a bottlenose dolphin (Tursiops truncatus). J Vet Diagn Invest 6: $448-452$

Felsenstein J (1985) Confidence limits on phylogenetics: an approach using the bootstrap. Evolution 39:783-791

> Ficht TA, Bearden SW, Sowa BA, Adams LG (1989) DNA sequence and expression of the 36-kilodalton outer membrane protein gene of Brucella abortus. Infect Immun 57: 3281-3291

> Forbes LB, Nielsen O, Measures L, Ewalt DR (2000) Brucellosis in ringed seals and harp seals from Canada. J Wildl Dis 36:595-598

> Foster G, Jahans KL, Reid RJ, Ross HM (1996) Isolation of Brucella species from cetaceans, seals and an otter. Vet Rec 138:583-586

Foster G, MacMillan AP, Godfroid J, Howie F and others (2002) A review of Brucella sp. infection of sea mammals with particular emphasis on isolates from Scotland. Vet Microbiol 90:563-580

Foster G, Osterman B, Godfroid J, Jacques I, Cloeckaert A (2007) Brucella ceti sp. nov. and Brucella pinnipedialis sp. nov. for Brucella strains with cetaceans and seals as their preferred hosts. Int J Syst Evol Microbiol 57:2688-2693

> Garner MM, Lambourn DM, Jeffries SJ, Briggs Hall P and others (1997) Evidence of Brucella infection in Parafila- 
roides lungworms in a Pacific Harbor seal (Phoca vitulina richardsi). J Vet Diagn Invest 9:298-303

Groussaud P, Shankster SJ, Koylass MS, Whatmore AM (2007) Molecular typing divides marine mammal strains of Brucella into at least three groups with distinct host preferences. J Med Microbiol 56:1512-1518

> Jacques I, Grayon M, Verger JM (2007) Oxidative metabolic profiles of Brucella strains isolated from marine mammals: contribution to their species classification. FEMS Microbiol Lett 270:245-249

Jahans KL, Foster G, Broughton ES (1997) The characterisation of Brucella strains isolated from marine mammals. Vet Microbiol 57:373-382

McDonald WL, Jamaludin R, Mackereth G, Hansen M and others (2006) Characterization of a Brucella sp. strain as a marine-mammal type despite isolation from a patient with spinal osteomyelitis in New Zealand. J Clin Microbiol 44: 4363-4370

Miller WG, Adams LG, Ficht TA, Cheville NF and others (1999) Brucella-induced abortion and infection in bottlenose dolphins (Tursiops truncatus). J Zoo Wildl Med 30: $100-110$

Ohishi K, Takishita K, Kawato M, Zenitani R and others (2004) Molecular evidence of new variant Brucella in North Pacific common minke whales. Microbes Infect 6:1199-1204

Ohishi K, Takishita K, Kawato M, Zenitani R and others (2005) Chimeric structure of omp2 of Brucella from Pacific common minke whales (Balaenoptera acutorostrata). Microbiol Immunol 49:789-793

Payeur JB, Carpenter L, Ewalt DR, Garner MM and others (1998) Evidence of Brucella species infection in Pacific harbor seals (Phoca vitulina richardsi), California sea lions (Zalophus californianus) and harbor porpoises (Phocoena phocoena) in Puget Sound, Washington. Proceedings of the ARC-Onderstepoort, OIE International Congress with

Editorial responsibility: Michael Moore, Woods Hole, Massachusetts, USA
WHO-Cosponsorship on anthrax, brucellosis, CBPP, clostridial and mycobacterial diseases. Berg-en-Dal, Kruger National Park, 9-15 August, p 173-177

Rhyan JC, Gidlewski T, Ewalt DR, Hennager SG, Lambourne DM, Olsen SC (2001) Seroconversion and abortion in cattle experimentally infected with Brucella sp. isolated from a Pacific harbor seal (Phoca vitulina richardsi). J Vet Diagn Invest 13:379-382

Ross HM, Foster G, Reid RJ, Jahans KL, MacMillan AP (1994) Brucella species infection in sea-mammals. Vet Rec 134: 359

Ross HM, Jahans KL, MacMillan AP, Reid RJ, Thompson PM, Foster G (1996) Brucella species infection in North Sea seal and cetacean populations. Vet Rec 138:647-648

Sanger F, Nicklen S, Coulson AR (1977) DNA sequencing with chain-terminating inhibitors. Proc Natl Acad Sci USA 74:5463-5467

Siebert U, Wünschmann A, Weiss R, Frank H, Benke H, Frese K (2001) Post-mortem findings in harbour porpoises (Phocoena phocoena) from the German North and Baltic Seas. J Comp Pathol 124:102-114

> Sohn AH, Probert WS, Glaser CA, Gupta N and others (2003) Human neurobrucellosis with intracerebral granuloma caused by a marine mammal Brucella spp. Emerg Infect Dis 9:485-488

Southern EM (1975) Detection of specific sequences among DNA fragments separated by gel electrophoresis. J Mol Biol 98:503-517

> Swenshon M, Lämmler C, Siebert U (1998) Identification and molecular characterization of beta-hemolytic streptococci isolated from harbor porpoises (Phocoena phocoena) of the North and Baltic Seas. J Clin Microbiol 36:1902-1906

Verger JM, Garin-Bastuji B, Grayon M, Mahe AM (1989) Bovine brucellosis caused by Brucella melitensis in France. Ann Rech Vet 20:93-120

Submitted: November 12, 2007; Accepted: March 17, 2008 Proofs received from author(s): June 21, 2008 